\title{
Front Matter: Volume 6797
}

, "Front Matter: Volume 6797," Proc. SPIE 6797, Manufacturing LEDs for Lighting and Displays, 679701 (2 October 2007); doi: 10.1117/12.772885

SPIE. Event: Manufacturing LEDs for Lighting and Display, 2007, Berlin, Germany 


\section{PROCEEDINGS OF SPIE}

\section{Manufacturing LEDs for Lighting and Displays}

Thomas P. Pearsall

Editor

10-11 September 2007

Berlin, Germany

Sponsored by

SPIE

Cosponsored by

EPIC-European Photonics Industry Consortium

SPIE Europe

Cooperating Organisations

Technische Universität Berlin (Germany)

Fraunhofer-Institut für Zuverlässigkeit und Mikrointegration (Germany)

LEDs Magazine (United Kingdom)

UK Displays \& Lighting (United Kingdom)

Published by

SPIE 
The papers included in this volume were part of the technical conference cited on the cover and title page. Papers were selected and subject to review by the editors and conference program committee. Some conference presentations may not be available for publication. The papers published in these proceedings reflect the work and thoughts of the authors and are published herein as submitted. The publisher is not responsible for the validity of the information or for any outcomes resulting from reliance thereon.

Please use the following format to cite material from this book:

Author(s), "Title of Paper," in Manufacturing LEDs for Lighting and Displays, edited by Thomas P. Pearsall, Proceedings of SPIE Vol. 6797 (SPIE, Bellingham, WA, 2007) Article CID Number.

ISSN 0277-786X

ISBN 9780819469656

Published by

SPIE

P.O. Box 10, Bellingham, Washington 98227-0010 USA

Telephone +1 3606763290 (Pacific Time) · Fax +1 3606471445

SPIE.org

Copyright (C) 2007, Society of Photo-Optical Instrumentation Engineers

Copying of material in this book for internal or personal use, or for the internal or personal use of specific clients, beyond the fair use provisions granted by the U.S. Copyright Law is authorized by SPIE subject to payment of copying fees. The Transactional Reporting Service base fee for this volume is $\$ 18.00$ per article (or portion thereof), which should be paid directly to the Copyright Clearance Center (CCC), 222 Rosewood Drive, Danvers, MA 01923. Payment may also be made electronically through CCC Online at copyright.com. Other copying for republication, resale, advertising or promotion, or any form of systematic or multiple reproduction of any material in this book is prohibited except with permission in writing from the publisher. The CCC fee code is 0277-786X/07/ $\$ 18.00$.

Printed in the United States of America.

Publication of record for individual papers is online in the SPIE Digital Library.

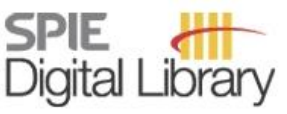

SPIEDigitalLibrary.org

Paper Numbering: Proceedings of SPIE follow an e-First publication model, with papers published first online and then in print and on CD-ROM. Papers are published as they are submitted and meet publication criteria. A unique, consistent, permanent citation identifier (CID) number is assigned to each article at the time of the first publication. Utilization of CIDs allows articles to be fully citable as soon they are published online, and connects the same identifier to all online, print, and electronic versions of the publication. SPIE uses a six-digit CID article numbering system in which:

- The first four digits correspond to the SPIE volume number.

- The last two digits indicate publication order within the volume using a Base 36 numbering system employing both numerals and letters. These two-number sets start with 00, 01, 02, 03, 04, 05 , $06,07,08,09,0 A, 0 B \ldots 0 Z$, followed by 10-1Z, 20-2Z, etc.

The CID number appears on each page of the manuscript. The complete citation is used on the first page, and an abbreviated version on subsequent pages. Numbers in the index correspond to the last two digits of the six-digit CID number. 


\section{Contents}

$\checkmark \quad$ Conference Committee

\section{OPENING PRESENTATION}

679702 Issues and solutions: opportunities for European LED manufacturers [6797-01]

T. P. Pearsall, European Photonics Industry Consortium (France)

\section{MARKETS AND APPLICATIONS}

679703 Markets and technology needs for UHB-LEDs (Invited Paper) [6797-02]

P. Roussel, Yole Développement (France)

679704 LEDs in automotive lighting and signaling: a customer point of view (Invited Paper) [6797-03]

S. Berlitz, C. Heider, AUDI AG (Germany)

\section{PHOSPHORS AND DISPLAYS}

6797 OA Advanced phosphors for LED applications (Invited Paper) [6797-09]

H. Winkler, H. Enderle, C. Kuehn, R. Petry, T. Vosgroene, MERCK KGaA (Germany)

\section{LED LIGHTING PRODUCTS}

6797 OD High performance LED lamps for the automobile: needs and opportunities (Invited Paper) [6797-12]

W. Pohlmann, T. Vieregge, M. Rode, Hella KGaA Hueck \& Co. (Germany)

6797 OE GalnN LEDs: straight way for solid state lighting (Invited Paper) [6797-13]

U. Zehnder, B. Hahn, J. Baur, M. Peter, S. Bader, H. J. Lugaver, A. Weimar, OSRAM Opto Semiconductors (Germany)

\section{POSTER SESSION}

6797 OF A silicon wafer packaging solution for HB-LEDs [6797-14]

T. Murphy, Hymite GmbH (Germany); S. Weichel, S. Isaacs, Hymite A/S (Denmark);

J. Kuhmann, Hymite GmbH (Germany)

6797 OG Phosphor-converted high power LEDs [6797-15]

R. Mueller-Mach, G. O. Mueller, M. R. Krames, Philips Lumileds Lighting Co. (USA) 
6797 Ol Comparison of different LED Packages [6797-17]

H. Dieker, C. Miesner, D. Püttjer, B. Bachl, Vossloh Schwabe Optoelectronic (Germany)

6797 0J Metal contacts to $p$-type GaN by electroless deposition [6797-18]

L. Lewis, D. Casey, J. F. Rohan, P. P. Maaskant, Tyndall National Institute (Ireland)

$6797 \mathrm{OL}$ Converter film technology for homogeneous white light [6797-20]

R. C. Jordan, J. Bauer, H. Oppermann, Fraunhofer-Institut für Zuverlässigkeit und

Mikrointegration (Germany)

6797 ON Improvement of ultra-high-brightness white LEDs [6797-22]

T. Mesli, Global Light Industries (Germany)

$679700 \quad$ Enhanced efficiency of near-UV emitting LEDs for solid state lighting applications [6797-23]

D. Zhu, Univ. of Cambridge (United Kingdom); B. Corbett, B. Roycroft, P. Maaskant, Tyndall National Institute (Ireland); C. McAleese, Univ. of Cambridge (United Kingdom); M. Akhter, Tyndall National Institute (Ireland); M. J. Kappers, C. J. Humphreys, Univ. of Cambridge (United Kingdom)

6797 OP Semiconductor nanowires for solid state lighting: simulation, epitaxy, integration, optical and electrical characterization [6797-24]

F. Lévy, Y. Désieres, P. Ferret, S. Fichet, S. Gidon, P. Gilet, P. Noel, I.-C. Robin, E. Romain-Latu, M. Rosina, R. Songmuang, G. Feuillet, CEA-LETI, MINATEC (France); B. Daudin, CEA-

Grenoble, DRFMC (France); A. Chelnokov, CEA-LETI, MINATEC (France)

6797 OR Thermal analysis of wafer-level LED packages with multichips [6797-26]

J.-W. Choi, J.-M. Kang, J.-W. Kim, J.-H. Choi, D.-H. Kim, G.-H. Kim, Y.-S. Song, Y.-H. Won,

J.-S. Lee, LG Electronics Institute of Technology (South Korea)

6797 OS Optical and structural characteristics of high-performance InGaN/GaN multiple quantum well light-emitting diodes: effects of nano-structural features [6797-27]

Z. S. Lee, Z. C. Feng, H. Tsai, J. Yang, National Taiwan Univ. (Taiwan); A. G. Li, ShenZhen Fangda GuoKe Optronics Technical Co. Ltd (China); L. C. Chen, National Taiwan Univ. (Taiwan); K. H. Chen, National Taiwan Univ. (Taiwan) and Academia Sinica (Taiwan); Y. F. Chen, National Taiwan Univ. (Taiwan); I. T. Ferguson, Georgia Institute of Technology (USA); W. LU, Fisk Univ. (USA)

6797 OX Influence of the barrier composition on the light output of InGaN multiple-quantum-well ultraviolet light emitting diodes [6797-34]

A. Knaver, V. Kueller, S. Einfeldt, V. Hoffmann, Ferdinand-Braun-Institut für Höchstfrequenztechnik (Germany); T. Kolbe, J.-R. van Look, Technische Univ. Berlin (Germany); J. Piprek, NUSOD Institute (USA); M. Weyers, Ferdinand-Braun-Institut für Höchstfrequenztechnik (Germany); M. Kneissl, Ferdinand-Braun-Institut für Höchstfrequenztechnik (Germany) and Technische Univ. Berlin (Germany)

6797 OY LED-driven backlights for automotive displays [6797-35]

F. Strauch, Harman/Becker Automotive Systems (Germany)

Author Index 


\title{
Conference Committee
}

\author{
Conference Chair
}

Thomas P. Pearsall, European Photonics Industry Consortium (France)

Programme Committee

Stephan Berlitz, Audi AG (Germany)

Gary Colquhoun, SPIE Europe Ltd. (United Kingdom)

Francois Creuzet, Saint-Gobain Recherche (France)

Carlos Domínguez, Centro Nacional de Microelectrónica (Spain)

Jochen Kunze, Global Light Industries (Germany)

Mario Musolino, SAES Getters S.p.A. (Italy)

Hermann Oppermann, Fraunhofer-Institut für Zuverlässigkeit und Mikrointegration (Germany)

Philippe Roussel, Yole Développement (France)

Henning Schroeder, Fraunhofer-Institut für Zuverlässigkeit und Mikrointegration (Germany)

Eric Vanlathem, Dow Corning Corporation (Belgium)

Peter Van Daele, IMEC (Belgium) and Universiteit Gent (Belgium)

Patrick R. Vandenberghe, Barco N.V. (Belgium)

\section{Session Chairs}

1 Markets and Applications

Eric Vanlathem, Dow Corning Corporation (Belgium)

2 Manufacturing Challenges

Gary Colquhoun, SPIE Europe Ltd. (United Kingdom)

3 Phosphors and Displays

Hermann Oppermann, Fraunhofer-Institut für Zuverlässigkeit und Mikrointegration (Germany)

$4 \quad$ LED Lighting Products

Philippe Roussel, Yole Développement (France) 
Downloaded From: https://www.spiedigitallibrary.org/conference-proceedings-of-spie on 26 Apr 2023

Terms of Use: https://www.spiedigitallibrary.org/terms-of-use 